\title{
O PATRIARCALISMO EM GABRIELA, CRAVO E CANELA: O ESTILHAÇAR DO RITUAL IDEOLÓGICO RADICAL
}

\section{PATRIARCHALISM IN GABRIELA, CRAVO E CANELA: THE SHATTERING OF THE RADICAL IDEOLOGICAL RITUAL}

\author{
Ana Patrícia Cavalcanti Queiroz \\ Mestre em Letras pela Universidade Federal do Amazonas \\ Membro do grupo de pesquisa Discurso e Práticas Sociais, liderado pelo professor Dr. Sérgio Augusto Freire de Souza \\ E-mail: anapatyqueiroz@hotmail.com
}

- não há dominação sem resistência [...] é preciso 'ousar se revoltar" [...] é preciso ousar 'pensar por si mesmo'. (PÊCHEUX, 1995, p. 304)

\section{RESUMO}

A obra Gabriela, cravo e canela, de Jorge Amado tem como cenário a cidade de Ilhéus, em 1925, quando o patriarcalismo tinha força e circulação. Nos propomos a analisar os personagens Malvina, Gabriela e Nacib a fim de traçar seus perfis subversivos e evidenciar como eles romperam com o discurso machista filiado a ideologia ${ }^{1}$ patriarcal que era circulado e, consequentemente, preservado na conjuntura Coronelista, na qual a mulher era marginalizada. Além disso, pretende-se relacionar a subversão desses personagens com o processo de desidentificação abordado por Pêcheux (1995). A partir de conceitos da Análise de Discurso (doravante AD), evidenciamos tanto a desidentificação de Malvina, Gabriela e Nacib quanto a dos cidadãos(-sujeitos) de Ilhéus no que concerne à ideologia e ao discurso vigente da época.

Palavras-chave: Patriarcalismo. Machismo. Desidentificação.

\section{ABSTRACT}

Gabriela, cravo e canela by Jorge Amado has Ilhéus city as scenario, in 1925, when patriarchalism used to be stronger and more preserved. We aim to analyse Malvina, Gabriela and Nacib in order to draw their subversive profiles and show how they broke with the sexist discourse affiliated to the patriarchal ideology which was circulated and, consequently, preserved in the social-historic conjecture they lived in. Besides, we intend to relate these characters' subversity to the desidentification process approached by Pêcheux (1995). By means of Discourse Analysis (hereafter DA) concepts, we will evidence not only Malvina, Gabriela and Nacib`s desidentification but also the one of the Ilheenses citizens(-subjects).

Key-words: Patriarchalism. Sexism. Desidentification. 


\section{INTRODUÇÃO}

Partindo do caráter social da literatura, este artigo se propõe a traçar o perfil subversivo de Malvina e do casal Gabriela e Nacib na obra Gabriela, cravo e canela de Jorge Amado. Observaremos como os três personagens romperam com o discurso machista filiado à ideol fía Patriarcal que era circulado e, consequentemente, preservado em uma conjuntura Coronelista, na qual a mulher, independente da classe social, era marginalizada.

O romance Gabriela, cravo e canela foi publicado pela primeira vez no ano de $1958 \mathrm{e}$ foi responsável pela entrada de Jorge Amado na Academia Brasileira de Letras, em 1961. Essa obra representa a ruptura de Jorge Amado com o discurso utópico de cunho social e seu deslocamento, pois foi a primeira das suas publicações em sua nova fase em que o sonho da Revolução, da conscientização do povo se dissolveu (GOLDSTEIN, 2003).

Esse romance representa a nova visão do Brasil e do mundo do autor. Sem receitas prontas, sem esquemas. Sua visão passou a ser viva, cheia de contradições, incoerências, nonsense. Ele se voltou, portanto, para o registro dos costumes sem o engajamento social que marcava suas obras até então. Esse fato não diminui, contudo, o papel das obras dessa fase nas discussões sociais.

Este artigo é dividido em cinco partes. Na primeira, faremos algumas considerações sobre a obra. Em seguida, abordaremos conceitos da $\mathrm{AD}$ que se relacionam com a subversividade dos personagens analisados. Em seguida, discorreremos sobre o caráter social da literatura e sobre o Coronelismo em Ilhéus. E, para melhor compreender com qual ideologia os personagens se (des)identificaram, apontaremos, em uma quarta parte, as características do Patriarcalismo no que tange ao papel da mulher. Vale explicar que, por mais que a conjuntura na qual a obra se insere seja a Coronelista, era a ideologia patriarcal que interpelava, seja às avessas ou não, os cidadãos de Ilhéus no que tange às mulheres. Por essa razão, não nos aprofundaremos no Coronelismo. Por fim, evidenciaremos o perfil subversivo dos personagens Malvina, Gabriela e Nacib frente ao discurso machista e à ideologia patriarcal relacionando suas rupturas com conceitos da $\mathrm{AD}$.

\section{GABRIELA, CRAVO E CANELA}

A ficção trabalhada neste artigo tem como cenário a cidade de Ilhéus, em 1925. Inicia com o assassinato de dona Sinhazinha Guedes Mendonça e de seu amante Dr. Osmundo Pimentel pelo marido traído, um fazendeiro rico, chamado Jesuíno Mendonça. No mesmo dia, 
Nacib perdeu sua cozinheira. A vaga na cozinha de Nacib foi o que permitiu que ele e Gabriela se conhecessem. A trama termina com a condenação do assassino. Podemos ver uma transformação da condição feminina em Ilhéus por ser inédito na cidade o julgamento por esse tipo de crime.

Nessa época, costumava-se derramar sangue para lavar a honra dos maridos traídos. Esse costume não estava escrito em código algum. Era uma questão ideológica originada dos senhores de antanho. Os ilheenses tinham um gosto por sangue derramado. Costumavam "arrotar valentia", "carregar revólveres dia e noite", e eram inclinados para apostas. Contudo, uma das poucas coisas em que os ilheenses não apostavam era na condenação do assassino por razão de adultério. Tinham a absolvição do "marido ultrajado" como justo e viam esse crime como um gesto louvável de macho. Contudo, como muitos outros costumes na cidade, esse começou a enfraquecer.

A cidade de Ilhéus estava em fase de desenvolvimento, em um rápido progresso e transformação. A palavra progresso era uma das mais faladas nas ruas de Ilhéus. Sua fisionomia estava a se modificar rapidamente. Contudo, havia uma forte contradição na cidade que, ao mesmo tempo que progredia, ainda contava com homens usando botas e carregando armas na rua. Era o passado misturado ao futuro.

No entanto, por mais lenta que a mudança de costume fosse, ela estava acontecendo. Médicos fazendo parto, bailes e tardes dançantes, a dança de Anabela com pouca roupa, bares, cinemas, cabarés, dentre outras. Tais mudanças na cidade não ocorreram sem resistência e eram vistas por muitos como “degradação", "degeneração de costumes”, “despropósito” e o progresso era visto como "imoralidade", "safadeza", assim como, as rupturas de mulheres com o discurso machista.

No que diz respeito à família e às mulheres, os ilheenses eram interpelados pela ideologia patriarcal. Na conjuntura na qual Ilhéus se encontrava, as mulheres ainda eram destinadas a casar, ser boas esposas e mães. Deviam obediência a seus pais e maridos, como dizia o coronel Ramiro Bastos: “[...] Mulher é para viver dentro de casa, cuidando dos filhos e do lar. Moça solteira é para esperar marido, sabendo coser, tocar piano, dirigir a cozinha. [...]" (AMADO, 2012, p. 66). Esses bons costumes eram reproduzidos pelas escolas, famílias e pelas igrejas, os quais davam às mulheres doses constantes de moralismo.

Contudo, esses valores podiam entrar em confronto com os das próprias mulheres. Havia aquelas que rompiam com os discursos vigentes e anelavam por liberdade, como Gabriela e Malvina. Ambas, a sua maneira e com motivações diferentes, não se submetiam às normas, ao 
padrão moral e social de sua época, à hierarquia patriarcal. De acordo com Belline, as duas personagens compartilhavam da "[...] ânsia de liberdade e o desejo de agir segundo a própria vontade." (2008, p. 31). Além delas, podemos mencionar Nacib que aparentava se identificar com os discursos que circulavam em sua cidade quando, na verdade, também desejava a liberdade.

Essa é uma das obras nas quais Jorge Amado retratou o papel da mulher em uma sociedade que circulava e preservava o discurso machista de filiação patriarcal. De acordo com Belline (2008, p. 27), na ficção de Jorge Amado, as mulheres “[...] transgrediam e superavam códigos injustos. [...]" deixando de ser objetos manipulados pelo homem e tornando-se "[...] sujeito de seu próprio destino - amoroso ou profissional.” Percebemos em suas obras, portanto, rupturas com discursos e busca por liberdade.

\section{INTERPELAÇÃO ÀS AVESSAS}

Diante do cenário descrito acima, o conceito de desidentificação emerge na análise dos personagens da obra Gabriela, cravo e canela. A desidentificação constitui um trabalho de transformação-deslocamento da forma-sujeito. É possível, portanto, romper com discursos, com ideologias, com a Formação Discursiva (doravante FD)2 em que se inscreve, e, por conseguinte, identificar-se com outra FD e sua respectiva forma-sujeito (PÊCHEUX, 1995).

A forma-sujeito-mulher de uma FD filiada ao Patriarcalismo caracteriza-se, como melhor abordaremos abaixo, pela submissão aos pais e aos maridos. Desidentificar-se com essa forma-sujeito é voltar-se contra o discurso machista e se identificar com outro(s). Segundo Zandwais (2003), a ruptura ocorre quando uma ideologia é contestada, questionada, quando duvidam e lutam contra suas evidências não-questionáveis e se revoltam.

Contudo, os indivíduos não deixam de ser interpelados em sujeitos, afinal eles são sempre já-sujeitos. O que ocorre é um deslocamento da ideologia, não uma anulação dela. Se desidentificam com uma ideologia ao se identificarem com uma nova. Em outras palavras, são interpelados às avessas, como Pêcheux coloca:

[...] A ideologia - 'eterna' enquanto categoria, isto é, enquanto processo de interpretação dos indivíduos em sujeitos - não desaparece; ao contrário, funciona de certo modo às avessas, isto é, sobre e contra si mesma, através do 'desarranjo-rearranjo' do complexo das formações ideológicas (e das formações discursivas que se encontram intricadas nesse complexo) [...]. (PÊCHEUX, 1995, p. 217 - 218).

Portanto, para a Análise de Discurso de linha francesa que tem Pêcheux como um de seus precursores, os indivíduos são sempre-já sujeitos. O sujeito discursivo é clivado, 
heterogêneo e divido entre consciência e inconsciência. Mesmo que ele continue assujeitado à uma ideologia, a ele é atribuída a possibilidade de "[...] situar-se frente ao interdiscurso, deslocando-se do já-dito, numa sujeição que já admite abertura.” (SOUZA, 2006, p. 95).

Em adição, o sujeito discursivo é tido como uma "posição", como um "lugar" que ocupa para ser sujeito do que diz. Dessa forma, os sujeitos são intercambiáveis. No Brasil Patriarcal e Coronelista, as mulheres falavam do lugar de filha, de esposa e de mãe. Considerando que o discurso está em conformidade com a conjuntura sócio-histórica, elas se assujeitavam àquela ideologia, àqueles discursos, os circulando, os reproduzindo e, consequentemente, os preservando (ou não).

A ideologia se manifesta nas práticas cotidianas que são reguladas por rituais definidos pelos Aparelhos Ideológicos de Estado (doravante AIE). Contudo, podemos falar com Pêcheux que não existe identificação total, plena, sem possibilidade de contradição, de falha no ritual da ideologia (PÊCHEUX, 2008). A resistência, cuja ordem é do inconsciente, estilhaça esse ritual da interpelação ideológica radical.

Vale mencionar que a desidentificação e a ruptura pressupõem consequências. Ao contrariar o discurso reproduzido pelos AIE, o sujeito recebe punições. Os AIE funcionam predominantemente pela ideologia e, secundariamente, pela repressão com limites e muitas vezes de forma simbólica.

[...] Assim, as escolas e igrejas dispõem de métodos adequados de punição, expulsão, seleção etc., para 'disciplinar' não apenas seus pastores, mas também seus rebanhos. O mesmo se aplica à família... E o mesmo se aplica ao AIE cultural (censura, entre outras coisas) etc. (ALTHUSSER, 1976, p. 116).

Contudo, a possibilidade de se deslocar, se transformar, se identificar com outra FD é constitutiva do sujeito discursivo. E isso foi o que aconteceu e acontece com diversas mulheres brasileiras e o que podemos observar nas mulheres representadas nas obras ficcionais de Jorge Amado. Mulheres que romperam com o discurso machista e com a ideologia patriarcal. Mulheres que não se submeteram a esse discurso e sofreram as consequências de suas rupturas. Mulheres a quem devemos o que conquistamos e somos hoje.

Como já mencionamos, por meio da obra Gabriela, cravo e canela, Jorge Amado retratou tanto a forma-sujeito-mulher em uma conjuntura que circulava e preservava o discurso machista de filiação patriarcal quanto a desidentificação com tal discurso. A narrativa retrata, também, o Coronelismo. Evidencia-se, por conseguinte, o forte caráter social da literatura sobre a qual abordaremos a seguir. 


\section{LITERATURA E SOCIEDADE: CORONELISMO REPRESENTADO}

A literatura é bastante influenciada pela cultura e pela sociedade em que fora produzida. Seu caráter social deve-se ao fato de ter como objeto de representação a realidade. Os autores sentem necessidade de expor sua visão de mundo, seja por engajamento social ou não. Sobre essa necessidade, podemos nos apoiar na seguinte citação:

[...] a criação literária corresponde a certas necessidades de representação do mundo, às vezes como preâmbulo a uma praxis socialmente condicionada. Mas isto só se torna possível graças a uma redução ao gratuito, ao teoricamente incondicionado, que dá ingresso ao mundo da ilusão e se transforma dialeticamente em algo empenhado, na medida em que suscita uma visão de mundo. (CANDIDO, 2006a, p. 65).

No que concerne à Literatura Brasileira, Candido alega que nossa literatura não nasceu aqui no Brasil, mas transformou-se à medida que a sociedade nova era formada. A literatura brasileira é resultado de imposição por parte da literatura de Portugal que era arraigada na cultura popular, como explica Candido:

[...] A literatura brasileira, como as de outros países do Novo Mundo, resulta desse processo de imposição, ao longo do qual a expressão literária foi se tornando cada vez mais ajustada a uma realidade social e cultural que aos poucos definia a sua particularidade. [...]. (CANDIDO, 1999, p. 12).

Novas realidades geravam novos sentimentos e novas formas de ver o mundo. A literatura começou a ganhar, então, seu timbre próprio. Expressavam ainda o social, contudo sem imposições da classe dominante, ou seja, passaram a ter como ponto de referência sua tradição local (CANDIDO, 1999). Essa fase cujo sistema literário já estava consolidado contava com Jorge Amado, criador dos personagens analisados neste artigo.

De acordo com Candido (2006b), é possível perceber a ligação entre a literatura e a sociedade quando descobrimos como as influências culturais e sociais, ao se incorporarem na estrutura da obra literária, tornam-se a própria substancia do ato criador. A realidade do povo baiano e das mulheres submetidas às injustiças em um país com discurso machista e patriarcal se tornaram, por sua vez, uma das substâncias do ato criador de Jorge Amado.

Ele trazia para a ficção a realidade da sua terra, a Bahia. Denunciava em sua obra, mesmo após desidentificar-se com o engajamento social, a opressão do trabalhador rural e das classes populares, o coronelismo latifundiário, dentre outros problemas que assolavam o nordeste do Brasil.

No que tange à política, Gabriela, cravo e canela retrata o Coronelismo, cujo chefe era o coronel Ramiro Bastos que chegou ao poder graças ao apoio do governador Seabra. Muitos dos 
coronéis de Ilhéus não eram realmente coronéis. Dava-se esse título aos donos de roça de mais de mil arrobas. Isso significa que ter o título de coronel, na maioria das vezes, implicava no reconhecimento da riqueza.

Aos coronéis, tudo era permitido. Frequentavam bordéis, se relacionavam com prostitutas e chegavam a comprar casas para manter suas amantes. Às esposas, cabia fazer os serviços domésticos. O funcionamento da família coronelista remetia aos costumes patriarcais. Essa era a ideologia - a patriarcal - que interpelava os indivíduos de Ilhéus, seja às avessas ou não.

$\mathrm{Na}$ obra, dentre diversos pontos, o discurso machista cuja filiação ideológica era a patriarcal foi denunciado. Discorreremos a seguir sobre a sociedade patriarcal com o objetivo de compreendermos o papel da mulher nela e, consequentemente, sua influência na constituição da família coronelista.

\section{SOCIEDADE PATRIARCAL: FILHAS, ESPOSAS E MÃES.}

Os portugueses viram na América tropical uma forma fácil de viver e de organizar qualquer modo de economia e tipo de sociedade. Desenvolveu-se, então, no Brasil, uma sociedade colonial patriarcal e aristocrática, principalmente em Pernambuco e na Bahia. (FREYRE, 2003). Estudar o Patriarcalismo é de grande importância visto que, de acordo com Freyre (2003) e Candido (1951), ele foi fundamental para a constituição da sociedade brasileira em níveis econômico, político e familiar.

A sociedade patriarcal era escravatória e polígama. Baseava-se e movia-se segundo o poder do pai. O senhor de engenho dominava a colônia quase sozinho. Ele era, segundo Freyre (2003), o verdadeiro dono do Brasil, dos homens e das mulheres.

Outras de suas características era o sadismo. O filho de família escravatória, em sua condição de senhor de escravos, tinha seu sadismo muitas vezes canalizado para outras áreas de sua vida, fortalecendo o seu gosto por mando. Esse gosto se encontrava "[...] refinado em um senso grave de autoridade e de dever [...]" (FREYRE, 2003, p. 114).

Uma das principais vítimas desse comportamento conquistador, dominador e autoritário dos senhores eram as mulheres. Elas eram escravas da dominação e do autoritarismo de seus pais e maridos. Como podemos observar na citação abaixo:

Resultado da ação persistente desse sadismo, de conquistador sobre conquistado, de senhor sobre escravo, parece-nos o fato, ligado naturalmente à circunstância econômica da nossa formação patriarcal, da mulher ser tantas vezes no Brasil vítima inerme do domínio ou do abuso do homem; criatura reprimida sexual e socialmente dentro da sombra do pai ou do marido. [...] (FREYRE, 2003, p. 114) 
Freyre (2003) não deixa de mencionar logo em seguida o sadismo da mulher, da esposa do senhor. Contudo, deixa claro que era motivado por ciúme ou inveja sexual que possuíam devido à poligamia de seus maridos.

De acordo ainda com ele, foi observado que, no início do século XIX, enquanto muitos pais não queriam que suas filhas aprendessem a ler e a escrever, outros as confinavam para aprender a ler, cozer e rezar. Ele relata também a experiência de uma inglesa que, ao visitar o Brasil no século XVIII, ficou horrorizada com a situação das mulheres. De acordo com essa visitante, elas eram ignorantes, beatas, não sabiam se vestir, exageravam nas joias e envelheciam rapidamente devido, provavelmente, aos muitos filhos que tinham e de suas vidas dentro de casa.

Candido (1951) defende que a dominação do marido não era tão absoluta quanto se dizia devido à participação ativa das esposas na sociedade doméstica e que as mulheres devem, em parte, ao Patriarcalismo sua capacidade de liderança e de iniciativa. $\mathrm{O}$ autor explica que a esposa era responsável por direcionar o trabalho dos escravos na cozinha, na costura e em outros setores; por administrar a plantação, a jardinagem e por cuidar dos filhos e dos animais. Contudo, percebemos nesses apontamentos que a incumbência da mulher era predominantemente doméstica.

No que concerne ao casamento, jovens, ou melhor, crianças com doze, treze ou quatorze anos já eram desposadas. Ter uma filha com quinze anos solteira era motivo de inquietação por parte dos pais. Esses passavam a fazer promessas a santos casamenteiros e a se preocupar com a possibilidade de sua filha virar "solteirona" aos 20 anos. Quanto mais novas, mais gosto sexual seus maridos teriam por elas, como explica Freyre:

[...] Porque depois de certa idade as mulheres pareciam não oferecer o mesmo sabor de virgens ou donzelas que aos doze ou aos treze aos. Já não conservavam o provocante verdor de meninas-moças apreciado pelos maridos de trinta, quarenta anos. Às vezes de cinquenta, sessenta, e até setenta. [...] (FREYRE, 2003, p. 429).

Conforme Freyre, as mulheres/jovens patriarcais ficavam em casa, recolhidas, cozinhavam para seus maridos e cuidavam dos filhos. Viviam uma vida de mulher quando, muitas delas, ainda eram crianças. Além disso, muitas morriam cedo no trabalho de parto (FREYRE, 2003).

Seus filhos e filhas eram criados com conservadorismo extremo. Eles deviam chamar seu pai e sua mãe de "senhor pai" e de "senhora mãe". Freyre diz que as mulheres também tinham que chamar seus maridos de "senhor". Mas que algumas começaram a chamá-los de "tu”, outras de "você", até que o tratamento colonial de "senhor" ficou menos rígido. O autor alega ainda que esposas e filhos dos patriarcas estavam, até esse ponto, em um nível semelhante ao dos escravos. 
As filhas moças recebiam uma educação ainda mais rígida no Patriarcalismo. Viviam, primeiramente, sob a tirania de seus pais e, depois sob a tirania de seus maridos. A elas eram negadas a independência e a voz (FREYRE, 2003). Estavam sempre rodeadas por pessoas mais velhas, sendo vigiada como em uma prisão. Casavam-se, na maioria das vezes, como já mencionamos, precocemente e abafavam suas paixões “[...] sob as carícias de maridos dez, quinze, vinte anos mais velhos; e muitas vezes inteiramente desconhecidos das noivas. Maridos da escolha ou da conveniência exclusiva dos pais. [...]” (FREYRE, 2003, p. 423).

Contudo, nem sempre a escolha dos pais era obedecida. Houve diversos casos de fugas românticas. E quando se casavam conforme as regras, havia casos de infidelidade conjugal. Há relatos de viajantes sobre esse último caso. Na Bahia, perceberam que senhoras só saiam de casa para ir à igreja, mas que encontravam formas de fugir da vigilância dos seus maridos ou de seus pais. Elas eram muitas vezes punidas, pois precisavam conseguir fugir também dos olhos das sogras, dos frades, das outras mulheres, de todos.

O médico inglês John White observou que as mulheres "mal-comportadas" eram de classe baixa. Essa estigmatização foi aos poucos perdendo força devido ao "malcomportamento" das mulheres da corte (FREYRE, 2003, p. 514). Na obra Gabriela, cravo e canela, teremos representantes das duas classes econômicas. Malvina de família rica, filha de um coronel e Gabriela, trabalhadora e humilde, casada com Nacib. Enquanto a classe social as dividia, seus desejos por liberdade as uniam.

\section{A SUBVERSÃO DE MALVINA E DO CASAL GABRIELA E NACIB}

Neste tópico, evidenciaremos o perfil subversivo dos personagens Malvina, Gabriela e Nacib frente ao discurso machista e à ideologia patriarcal, relacionando suas rupturas com conceitos da AD.

\subsection{MALVINA: NASCIDA PARA UM GRANDE DESTINO}

Malvina era filha única do coronel Melk Tavares e aluna do colégio de freiras. Morava em uma casa moderna apenas no estilo. Ela possuía uma "expressão de súplica e desesperança" e "olhos fundos e misteriosos". Ela não se identificava com o discurso de sua época e rompia constantemente com ele.

Costumava conversar com o professor Josué no portão da sua casa, o que levava as solteironas ao escândalo. Além disso, foi recriminada por ir ao funeral da esposa que foi morta 
por adultério no início da trama. Nacib disse nesse momento que Malvina tinha topete, ou seja, que ela era ousada. Pensando sobre a ida da jovem ao funeral, Nacib lembrou de algo que João Fulgêncio havia dito:

[...] Uma vez João Fulgêncio dissera, ao vê-la com outras colegas comprando chocolate no bar:

— Essa moça é diferente das outras, tem caráter.

Por que diferente, que queria dizer João Fulgêncio, homem tão ilustrado, com aquela coisa de "caráter"? A verdade é que ela aparecera no velório, levando flores. O pai visitara Jesuíno, "lavara-lhe o seu braço", como ele mesmo dissera a Nacib no "mercado dos escravos". A filha, moça solteira e estudante, à espera de noivo, que diabo fora fazer junto ao caixão de Sinhazinha? Tudo dividido, o pai de um lado, a filha de outro. Esse mundo é complicado, entenda-o quem quiser, estava acima de suas forças, não passava de dono de bar, por que pensar em tudo isso? Tinha era de ganhar dinheiro para um dia comprar roça de cacau. [...] (AMADO, 2012, p. 147).

Ela era realmente diferente de muitas outras, pois era "nascida para um grande destino, presa em seu jardim". Esse era seu maior segrego que foi desvendado no capítulo terceiro da obra. Em seguida, o capítulo trouxe a Cantiga para ninar que retratava sua inquietação frente aos costumes reproduzidos pelos AIE - o casamento arrumado -, como podemos ver na seguinte parte da cantiga:

\section{$[\ldots]$}

Acudam! vão me casar numa casa me enterrar na cozinha a cozinhar na arrumação a arrumar no piano a dedilhar na missa a me confessar. Acudam! vão me casar na cama me engravidar.

[...]

Meu marido, meu senhor na minha vida a mandar. A mandar na minha roupa no meu perfume a mandar. A mandar no meu desejo no meu dormir a mandar. A mandar nesse meu corpo nessa minh'alma a mandar. Direito meu a chorar.

Direito dele a matar.

No teu leito adormecida partirás a navegar.

Acudam! me levem embora quero marido pra amar não quero pra respeitar. $[\ldots]$

(AMADO, 2012, p. 152)

A jovem conheceu, então, Rômulo Vieira, engenheiro do Ministério da Aviação. Costumavam passear pelas ruas de Ilhéus conversando e rindo bastante. Esse relacionamento 
causou comentários por toda parte, o arregalamento dos olhos das solteironas e mães proibindo suas filhas de andarem com ela, como Dona Felícia, mãe de Iracema. Afinal, ela estava namorando com um homem casado. O trecho abaixo é referente ao dia em que ela e Rômulo dançaram juntos em um baile.

Velhas e jovens cochichavam na sala de baile, detalhando vestidos, jóias, enfeites, maliciando namoros, prevendo noivados. No mais belo vestido da noite, mandado vir da Bahia, Malvina era o vivo e comentado escândalo. Ninguém mais desconhecia na cidade a condição de homem casado do engenheiro da barra, separado da mulher. Louca incurável internada em hospício, é bem verdade. Mas isso que importava, era um homem sem direito a olhar para moça solteira, casadoira. Que tinha ele para lhe oferecer além da desonra, no mínimo deixá-la falada, na boca do mundo, sem nunca mais conseguir casamento [...] (AMADO, 2012, p. 190).

Ao descobrir o namoro, o pai de Malvina ameaçou o engenheiro e o deu dois dias para deixar a cidade. Chegando em casa, questionou ferozmente o namoro da jovem com um homem casado e perguntou o que ela tinha a dizer sobre isso. Malvina se posicionou contra o discurso machista e dominador de seu pai de forma explícita nesse momento e sofreu represálias.

\section{$[\ldots]$}

- Que adianta dizer? O senhor não vai compreender. Aqui ninguém pode me compreender. Já lhe disse, meu pai, mais de uma vez: eu não vou me sujeitar a casamento escolhido por parente, não vou me enterrar na cozinha de nenhum fazendeiro, ser criada de nenhum doutor de Ilhéus. Quero viver a meu modo. Quando sair, no fim do ano, do colégio, quero trabalhar, entrar num escritório.

— Tu não tem querer. Tu há de fazer o que eu ordenar.

— Eu só vou fazer o que eu desejar.

-O que?

- O que eu desejar..

— Cala a boca, desgraçada!

- Não grite comigo, sou sua filha, não sou sua escrava.

— Malvina! - exclamou a mãe. - Não responda assim a seu pai.

Melk segurou-lhe o pulso, bateu-lhe a mão na cara. Malvina reagiu:

- Pois vou embora com ele, fique sabendo.

- Ai, meu Deus!... - a mãe cobriu o rosto com as mãos.

- Cachorra! - levantou o rebenque, nem reparou onde batia.

Foi nas pernas, nas nádegas, nos braços, no rosto, no peito. Do lábio partido o sangue escorreu, Malvina gritou:

— Pode bater. Vou embora com ele!

- Nem que te mate...

Num repelão atirou-a contra o sofá. Ela caiu de bruços, novamente ele levantou o braço, o rebenque descia e subia, silvava no ar. Os gritos de Malvina ecoavam na praça.

A mãe suplicava, em choro a voz medrosa:

- Basta, Melk, basta...

Depois, de repente, se atirou da porta, agarrou-lhe a mão:

— Não mate minha filha!

Parou, arquejante. Malvina agora apenas soluçava no sofá.

— Pro quarto! Até segunda ordem, não pode sair.

[...] (AMADO, 2012, p. $214-216)$ 
Malvina temia ser infeliz como sua mãe que representa, na obra, a mulher submissa ao discurso machista de uma sociedade com regras patriarcais pré-estabelecidas. Ela só ia a igreja, não se envolvia com os negócios. Sua condição pode ser resumida no trecho abaixo:

[...] Melk com todos os direitos, de tudo decidindo. A mãe cuidando da casa, era seu único direito. O pai nos cabarés, nas casas de mulheres, gastando com raparigas, jogando nos hotéis, nos bares, com os amigos bebendo. A mãe a fenecer em casa, a ouvir e a obedecer. Macilenta e humilhada, com tudo conforme, perdera a vontade, nem na filha mandava (AMADO, 2012, p. 218).

A jovem jurava desde mocinha que não teria uma vida como a de sua mãe. Não se sujeitaria às vontades de seu pai e aos discursos vigentes em sua conjuntura. Seu pai percebia que Malvina queria ser mais. “[...] Reconhecia-se nela, em certos detalhes, no desejo de ser. Mas a exigia obediente. [...]" (AMADO, 2012, p. 218). Quando Malvina disse que gostaria de cursar o ginásio e faculdade, recebeu a seguinte resposta: “- Não quero filha doutora. Vai pro colégio das freiras, aprender a costurar, contar e ler, gastar seu piano. Não precisa de mais. Mulher que se mete a doutora é mulher descarada, que quer se perder" (AMADO, 2012, p. 218).

Essa resposta está de acordo com os moldes patriarcais nos quais as filhas são ou isoladas do mundo ou instruídas para serem "melhores” mães e esposas no futuro. Após receber tal resposta, ela teve certeza do que não queria para sua vida. "Dera-se conta da vida das senhoras casadas, igual à da mãe. Sujeitas ao dono. Pior do que freira. Malvina jurava para si mesma que jamais, jamais, nunca jamais se deixaria prender. [...]" (AMADO, 2012, p. 218).

O Patriarcalismo que tanto a afligia é retratado no trecho abaixo no qual observamos filhos homens fazendo faculdade enquanto as moças nem ginásio podiam fazer, moças tratadas como objetos que podiam ser entregues a quem quer que o pai desejasse e esposas sendo tratadas como escravas, serviçais.

[...] Conversavam no pátio do colégio, juvenis e risonhas, filhas de pais ricos. Os irmãos na Bahia, nos ginásios e faculdades. Com direito a mesadas, a gastar dinheiro, a tudo fazer. Elas só tinham para si aquele breve tempo de adolescência. As festas do Clube Progresso, os namoros sem consequência, os bilhetinhos trocados, tímidos beijos furtados nas matinês dos cinemas, por vezes mais fundos dos portões nos quintais. Chegava um dia o pai com um amigo, acabava o namoro, começava o noivado. Se não quisesse, o pai obrigava. Acontecia uma casar com o namorado, quando os pais faziam gosto no rapaz. Mas em nada mudava a situação. Marido trazido, escolhido pelo pai, ou noivo mandado pelo destino, era igual. Depois de casada, não fazia diferença. Era o dono, o senhor, a ditar as leis, a ser obedecido. Para ele os direitos, para elas o dever, o respeito. Guardiãs da honra familiar, do nome do marido, responsáveis pela casa, pelos filhos. (AMADO, 2012, p. 218).

Malvina tinha uma alma inquieta e um desejo muito forte de libertar-se daquela repressão, representada metaforicamente na obra pelos sapatos. Após ser agredida e humilhada por seu pai, ela foi ao rochedo esperar pelo seu amado Rômulo para fugirem, “[...] descalça, os 
sapatos na mão, o olhar decidido [...]" (AMADO, 2012, p. 216). Tirar os sapatos foi libertar-se das amarras, das regras, do enclausuramento, da repressão. Seus princípios e suas verdades iam de encontro com o discurso vigente. Afinal, “[...] Odiara desde cedo a casa, a cidade, as leis, os costumes. A vida humilhada da mãe a tremer ante Melk, a concordar, sem ser consultada para os negócios. [...]" (AMADO, 2012, p. 217).

Ao perceber que Rômulo não iria ao seu encontro, pensou em se matar. Contudo, ela desistiu rapidamente, pois queria viver, queria sair de lá. Nesse momento, Malvina rompeu novamente com o discurso machista ao se perguntar:

[...] Por que partir pela mão de alguém, presa a um compromisso, a dívida tão grande? Por que não partir com seus pés, sozinha, um mundo a conquistar? Assim sairia. Não pela porta da morte, queria viver e ardentemente, livre como o mar sem limites. Segurou os sapatos, desceu dos rochedos, começou a esboçar um plano. Sentia-se leve. Melhor do que tudo fora ele não ter vindo, como poderia viver com um homem covarde? (AMADO, 2012, p. 221).

No trecho acima, percebemos novamente a relação entre sapatos e repressão. Ao decidir ir "com seus pés", Malvina decide se libertar de qualquer vestígio de dominação masculina. Ela se desidentificou com o discurso de dominação masculina, machista e com a ideologia patriarcal a qual tantas mulheres eram assujeitadas na época e se identificou, consequentemente, com o discurso feminista, de independência e de liberdade.

O clímax de sua desidentificação, isto é, de sua transformação e deslocamento, foi sua fuga para São Paulo onde passou a trabalhar em um escritório, estudar a noite e morar sozinha. É importante mencionar que Malvina sofreu as consequências da ruptura com o discurso machista. Ela foi rotulada, por alguns ilheenses, de "desgraçada", "cachorra", "indigna", "escândalo indecente", "mau exemplo citado". Foi agredida, humilhada, internada no Colégio das Mercês na Bahia e, após sua fuga, rejeitada por seu próprio pai. Não há rupturas sem consequências e em alguns casos, tais consequências podem ser bastante duras. Contudo, não há ruptura sem a sensação de liberdade, de independência, de satisfação e de pés descalços.

\subsection{GABRIELA E NACIB: O AMOR ACIMA DE TUDO}

Ao chegar em Ilhéus, fugida da seca, a mulata Gabriela começou a cozinhar no Bar Vesúvio de Nacib. Os dois se apaixonaram e, por medo de ser abandonado, Nacib a pediu em casamento. Essa história de amor foi "[...] o centro de toda a vida da cidade naquele tempo, quando o impetuoso progresso e as novidades da civilização transformavam a físionomia de Ilhéus." (AMADO, 2012, p. 18). 
Gabriela gostava de Nacib e chegou a recusar propostas de outros homens antes mesmo de se casar com ele. Ela estava feliz com o que possuía, menos com os sapatos que a apertavam e que Nacib tanto insistia para que ela usasse.

Estava contente com o que possuía, os vestidos de chita, as chinelas, os brincos, o broche, uma pulseira, dos sapatos não gostava, apertavam-lhe os pés. Contente com o quintal, a cozinha e seu fogão, o quartinho onde dormia, a alegria cotidiana do bar com aqueles moços bonitos [...], contente com o negrinho Tuísca seu amigo, com seu gato conquistado ao morro. (AMADO, 2012, p. 182).

Aqui, a metáfora dos sapatos se repete. Percebemos que, por mais que ela gostasse de Nacib, Gabriela anelava por liberdade e pelo desapego aos costumes da nata sociedade, da burguesia tão reproduzidos em Ilhéus. Mas estava disposta a "reprimir os seus pés" para poder se adequar ao discurso e à ideologia que Nacib se identificava. Ela dizia:

Essa dona Arminda, com tanto espiritismo, estava era ficando maluca. Que ideia sem pés nem cabeça, aquela do casamento com seu Nacib. Que era bom de pensar, ah! era bom... Dar o braço a ele, sair andando na rua. Mesmo que fosse de sapato apertado. Entrar no cinema sentar junto dele, encostar a cabeça no ombro macio como um travesseiro. Ir a uma festa, dançar com seu Nacib. Aliança no dedo... (AMADO, 2012, p. 182)

No entanto, a identificação de Nacib com o discurso machista estava apenas no seu imaginário, na forma-sujeito ideal daquela FD. Seu desejo (in)consciente de adequar-se à forma o levava a dizer e a fazer o que podia e devia dizer e fazer naquela FD. Portanto, ele tinha “[...] a ilusão de controle do dizer e, por sua vez, do sentido, sob o efeito de um lugar social, construído pela 'norma identificadora' da sociedade [...]" (GRIGOLETTO, 2005, p. 64).

Como todos sujeitos discursivos, ele era fragmentado ideologicamente, heterogêneo assim como o seu discurso. A heterogeneidade e a contradição em seu discurso são evidenciadas por meio da mesma metáfora recorrente - sapatos. Ele também sentiu prazer em arrancar os sapatos, ou seja, em se libertar da (re)pressão e do assujeitamento àquela ideologia. Sentia prazer na liberdade, como podemos observar no trecho a seguir: "Entrou na sala, arrancou os sapatos. Ficava grande parte do dia em pé, andando de mesa em mesa. Um prazer tirar os sapatos, as meias, mexer os dedos dos pés, dar uns passos descalços, enfiar os velhos chinelos cara de gato.” [...] (AMADO, 2012, p. 146).

Acreditando na identificação de Nacib com aquela ideologia, Gabriela chegou a pensar que ele devia se casar com mulher distinta, sem vício de homem, que calçasse sapatos. Ela se via apenas cozinhando, arrumando casa, lavando roupa e deitando com homem só pelo prazer de se deitar. Contudo, eles se casaram e tiveram uma linda festa. 
Após o matrimônio, as exigências e repreensões de Nacib ficaram mais frequentes. Ele queria torná-la igual às esposas dos médicos e advogados. A repreendia quanto a sorrir muito, quanto a ir ao circo, a falar alto, a não fechar as pernas ao sentar, a roupa, aos sapatos, a todo o seu comportamento.

Ao comprar um par de sapatos novos para Gabriela, ele pensou: “[...] Andava descalça o tempo todo em casa, vinha de chinelas ao bar, não ficava bem. [...]” (AMADO, 2012, p. 169). Ao dizer que "não ficava bem", percebemos a sua preocupação (in)consciente com a adaptação ao discurso vigente. Após o matrimônio, ele disse que ela precisava andar calçada pois era agora uma senhora, de posses e de representação.

Gabriela questionava essas exigências, mas, com o intuito de não desagradar Nacib, acabava cedendo e usando os tais sapatos que a faziam sofrer e que representavam um discurso de submissão com o qual ela não conseguia se identificar, como veremos a seguir:

[...] Gabriela estaria de mantilha rendada, vestida de seda, com apertados sapatos. No baile sentada, de olhos baixos, calada, sem saber como se comportar. [...] (AMADO, 2012, p. 298).

[...] Gabriela que mal podia manter-se de pé. Sapato infeliz apertava-lhe a ponta do dedo. Não nasceram seus pés para andar calçados. [...] (AMADO, 2012, p. 302).

Já em crise conjugal (e ideológica), ela realizou uma de suas rupturas - descalçou os seus pés e, desobedecendo seu marido, correu para frente do terno que tanto queria participar. “[...] Seu corpo rodou, suas ancas partiram, seus pés libertados a dança criaram. [...]” (AMADO, 2012, p. 303).

Infeliz com o confinamento de seu casamento e com os tão apertados sapatos, a vida sexual do casal esfriou. Gabriela, por conseguinte, cedeu aos seus impulsos sexuais e teve um caso com Tonico Bastos. Ela tinha uma sexualidade aflorada, gostava de "dormir por dormir". Diferente do que se esperava da forma-sujeito-mulher daquela época, ela sabia diferenciar amor e sexo.

A consequência de infidelidade em Ilhéus era geralmente a morte, como ocorreu no início da trama. Nacib costumava dizer o seguinte: “_ [...] Eu, se fosse casado e minha mulher me iluminasse a testa, ah!, comigo era na lei Síria: picadinho com o corpo dela... Não faria por menos." (AMADO, 2012, p. 111). Contudo, ele estava apenas obedecendo ao discurso vigente, protegendo (in)conscientemente sua imagem. Ele dizia o que era permitido dizer naquela Formação Social na qual se inseria e na FD na qual se inscrevia. Na verdade, ele não compactuava com tais costumes, não era de sua natureza matar alguém. Para ele, mulher alguma merecia a morte. Portanto, quebrando a lei antiga, ou seja, rompendo com o discurso vigente, 
Nacib não matou Gabriela. Mesmo agredindo a ela e ao seu amante sem dó e anulando o matrimônio, percebemos sua subversão por ele não ter feito o que se esperava da forma-sujeitomacho daquela época.

A tristeza de Nacib e seu amor por Gabriela influenciaram ainda mais o seu processo de desidentificação. Além de não seguir a lei antiga da morte por adultério, ele também rompeu com o discurso machista e patriarcal ao respeitar o fato de que Gabriela não se submeteria aos padrões morais e sociais do Patriarcalismo e ao reatar o relacionamento. Se identificou com o discurso do amor e, também, com o da liberdade.

Em suma, podemos perceber que Gabriela tentou e, de certa forma, foi forçada, mas não se identificou com o discurso burguês e machista. Ela rompeu com esses discursos ao desafiar os padrões da alta sociedade, tirando seus sapatos e correndo para o terno, e ao ser infiel. Até Gabriela ser compreendida por Nacib, ela apanhou e teve o matrimônio anulado. Faz-se importante ressaltar que se ela não tivesse se posicionado contra os discursos daquela conjuntura, seu casamento provavelmente não seria feliz e Nacib não teria rompido com o discurso que aparentava tanto preservar até então.

\section{CONSIDERAÇÕES FINAIS}

Como já mencionado, não há dominação sem resistência. Foi pela resistência que a mulher brasileira se constituiu e se constitui até os dias de hoje. Resistência ao machismo, à desigualdade no mercado de trabalho e na participação política. Resistência à sua inferiorização e dominação. É importante mencionar que nenhum desses fatores estão extintos. Ainda hoje, é possível observar a influência do Patriarcalismo na sociedade brasileira, em sua política, em sua família, em sua igreja, no "jeitinho brasileiro" e nas questões femininas. O machismo, portanto, mesmo que revestido com novas roupagens, ainda está presente em nosso meio.

Jorge Amado, muito antes dos movimentos feministas, já retratava a existência e a necessidade dessa resistência. Sua obra foi capaz de fomentar discussões e reflexões acerca da mulher brasileira. Por meio de Gabriela, cravo e canela, obra que é por si mesma uma ruptura, o autor buscou representar sua visão de mundo e retratou o contraditório como uma condição intrinsecamente humana, como uma condição ilheense.

Em Ilhéus, enquanto uns estavam fortemente inscritos na forma-sujeito-patriarcal e machista, como Diógenes, coronel Melk Tavares e coronel Ramiro Bastos, outros foram interpelados às avessas por essa ideologia, como Mundinho Falcão, Tonico Bastos e Anabela, a 
dançarina. As FDs, passíveis de transformações, estavam em um acelerado processo de deslocamento nessa cidade.

Como cidadãos ilheenses e como sujeitos discursivos, os personagens discutidos neste artigo se voltaram contra o discurso machista filiado ao Patriarcalismo ao contestá-lo e questioná-lo, como Gabriela o fez, ao duvidar e lutar contra suas evidências não-questionáveis, como Nacib o fez, e ao revoltar-se, como Malvina o fez.

Malvina, Gabriela e Nacib, assim como alguns cidadãos ilheenses, representam a resistência. Questionaram, se revoltaram e, por fim, se deslocaram e se identificaram com outros discursos: o do progresso, o do amor, o da independência, o do feminismo, o da liberdade, o dos pés descalços.

\section{NOTAS}

${ }^{1}$ Entendemos ideologia como uma formação trans-histórica que interpela os indivíduos em sujeitos por meio dos Aparelhos Ideológicos de Estado (doravante AIEs), isto é, por meio da escola, da família, da justiça, dos partidos, dos sindicatos políticos, da mídia e das igrejas (ALTHUSSER, 1976). Ela sobredetermina o funcionamento da vida social.

${ }^{2}$ FD é "[...] aquilo que, numa formação ideológica dada, isto é, a partir de uma posição dada numa conjuntura dada, determinada pelo estado da luta de classe, determina o que pode e deve ser dito [...]" (PÊCHEUX, 195, p. 160)

\section{REFERÊNCIAS}

AMADO, Jorge. Gabriela, cravo e canela: crônica de uma cidade do interior. $2^{\mathrm{a}}$ ed. São Paulo: Companhia das Letras, 2012.

ALTHUSSER, Louis. Ideologia e Aparelhos ideológicos de Estado. Paris: Editions Sociales, 1976. In: ŽIŽEK, Slavoj. Um mapa da ideologia. Tradução de Vera Ribeiro. Rio de Janeiro: Contraponto, 1996.

BELLINE, Ana Helena Cizotto. Representações do feminino. In: GOLDSTEIN, Norma Seltzer. A literatura de Jorge Amado: Orientações para o trabalho em sala de aula. 1 ed. São Paulo: Companhia das Letras, 2008, p. 26-35. Disponível em: $<$ http://www.companhiadasletras.com.br/sala_professor/pdfs/CadernoLeiturasAliteraturadeJorge Amado.pdf>. Acesso em: 26 out 2014.

CANDIDO, Antonio. The Brazilian Family. In: Smith, T. L. e Marchant, A. (Eds), Brazil, portrait of a continent. N. Y.: The Dryden Press, 1951. Não paginado.

. Iniciação à Literatura Brasileira: resumo para principiantes. São Paulo: Humanitas Publicações, 1999.

. Literatura e Sociedade. 9. ed. Rio de Janeiro: Ouro sobre Azul, 2006a. 
$2006 \mathrm{~b}$.

. Literatura de dois gumes. A Educação Pela Noite. Rio de Janeiro: Ouro Sobre Azul,

FREYRE, Gilberto. Casa-grande \& senzala: formação da família brasileira sob o regime da economia patriarcal. 48 ed. São Paulo: Global, 2003.

GOLDSTEIN, Ilana Seltzer. O Brasil best seller de Jorge Amado: literatura e identidade nacional. São Paulo: SENAC, 2003.

GRIGOLETTO, Evandra. A noção de Sujeito em Pêcheux: uma Reflexão acerca do Movimento de desidentificação. Vitória da Conquista, $n^{0}$ 1, p. 61-67, junho, 2005.

PÊCHEUX, Michel. Semântica e discurso: uma crítica à afirmação do óbvio. Tradução de Eni P. Orlandi [et al.]. 2a ed. Campinas, SP: Editora UNICAMP, 1995.

SOUZA, Sérgio Augusto Freire de. Conhecendo Análise de Discurso: Linguagem, Sociedade e Ideologia. Manaus: Editora Valer, 2006.

ZANDWAIS, Ana. A forma-sujeito do discurso e suas modalidades de subjetivação: um contraponto entre saberes e práticas. In: Actas do I SEAD, Porto Alegre, 2003 (no prelo). 